\title{
The Corticotropin-Releasing Hormone Network and the Hypothalamic-Pituitary-Adrenal Axis: Molecular and Cellular Mechanisms Involved
}

\author{
Juan José Bonfiglio ${ }^{a}$ Carolina Inda $^{a}$ Damián Refojo $^{b}$ Florian Holsboer ${ }^{b}$ \\ Eduardo Arzt $^{\mathrm{a}}$ Susana Silberstein ${ }^{\mathrm{a}}$ \\ a Laboratorio de Fisiología y Biología Molecular, Departamento de Fisiología y Biología Molecular y Celular, \\ Facultad de Ciencias Exactas y Naturales (FCEN), Universidad de Buenos Aires, and IBioBA-CONICET-Partner \\ Institute of the Max Planck Society, Buenos Aires, Argentina; ${ }^{b}$ Max Planck Institute of Psychiatry, Munich, Germany
}

\section{Key Words}

HPA axis $\cdot \mathrm{CRH}$ signaling $\cdot \mathrm{CRH}$ receptor $\cdot \mathrm{B}$-Raf $\cdot$ MAPK

\begin{abstract}
Corticotropin-releasing hormone $(\mathrm{CRH})$ plays a key role in adjusting the basal and stress-activated hypothalamic-pituitary-adrenal axis (HPA). CRH is also widely distributed in extrahypothalamic circuits, where it acts as a neuroregulator to integrate the complex neuroendocrine, autonomic, and behavioral adaptive response to stress. Hyperactive and/or dysregulated CRH circuits are involved in neuroendocrinological disturbances and stress-related mood disorders such as anxiety and depression. This review describes the main physiological features of the $\mathrm{CRH}$ network and summarizes recent relevant information concerning the molecular mechanism of $\mathrm{CRH}$ action obtained from signal transduction studies using cells and wild-type and transgenic mice lines. Special focus is placed on the MAPK signaling pathways triggered by $\mathrm{CRH}$ through the $\mathrm{CRH}$ receptor 1 that plays an essential role in $\mathrm{CRH}$ action in pituitary corticotrophs and in specific brain structures. Recent findings underpin the concept of specific CRHsignaling pathways restricted to specific anatomical areas. Understanding $\mathrm{CRH}$ action at molecular levels will not only provide insight into the precise $\mathrm{CRH}$ mechanism of action, but will also be instrumental in identifying novel targets for pharmacological intervention in neuroendocrine tissues and specific brain areas involved in $\mathrm{CRH}$-related disorders.
\end{abstract}

Copyright $\odot 2011$ S. Karger AG, Basel

\section{KARGER}

Fax +4161306 1234

E-Mail karger@karger.ch

www.karger.com
(C) 2011 S. Karger AG, Basel

0028-3835/11/0941-0012\$38.00/0

Accessible online at:

www.karger.com/nen

\section{Corticotropin-Releasing Hormone System and Stress: Physiological Framework}

Corticotropin-Releasing Hormone: A Major Player of the HPA Axis

Corticotropin-releasing hormone $(\mathrm{CRH})$ is a 41 -amino acid peptide that has a key role in the adjustment of neuroendocrine, autonomic, and behavioral adaptations to stress $[1,2]$. One major neuroendocrine system involved in mediating the stress response is the hypothalamic-pituitary-adrenal (HPA) axis. Hypothalamic CRH neurons drive both basal and stress-induced HPA activation. Internal homeostasis or changes in external environmental stress are conveyed to the central nervous system (CNS) by neurochemical pathways and are integrated at the hypothalamic level where they reach paraventricular (PVN) CRH neurosecretory neurons controlling $\mathrm{CRH}$ secretion. $\mathrm{CRH}$ activates adrenocorticotropin (ACTH) secretion from the corticotrophs of the anterior pituitary gland, which in turn stimulates corticosteroid release from the adrenal cortex [3].

The CRH effect at the pituitary level is amplified by arginine vasopressin (AVP), which is expressed in the supraoptic nucleus and PVN, and coexpressed and cosecreted from hypothalamic $\mathrm{CRH}$ neurons after enduring stress [4]. A large number of neuronal circuits stimulate $\mathrm{CRH}$ and AVP-secreting neurons in the PVN, i.e. brain limbic pathways carrying external information and ascending

Susana Silberstein

Laboratorio de Fisiología y Biología Molecular, FCEN

Universidad de Buenos Aires, Ciudad Universitaria

Buenos Aires 1428 (Argentina)

Tel. +54 114576 3368, E-Mail ssilberstein@fbmc.fcen.uba.ar 
brainstem pathways conveying visceral and sensory stimuli [2]. CRH and AVP mediate ACTH release via different second messenger systems and the cellular mechanism underlying the synergistic effect of $\mathrm{CRH}$ and AVP on ACTH release is not completely understood. Pituitary ACTH stimulates the adrenal cortex to secrete glucocorticoids, cortisol (in humans) and corticosterone (in humans and rodents), which support the adaptation to stressinduced demands by controlling energy metabolism, disposition, and storage [2]. Corticosteroids are released in a pulsatile ultradian pattern that may vary in amplitude and frequency under stressful conditions. Glucocorticoids are negative regulators of the HPA axis acting through two types of receptors: the glucocorticoid receptor (GR) and the mineralocorticoid receptor. GRs and mineralocorticoid receptors expressed in hypothalamic CRH/AVP neurons and pituitary corticotrophs drive the negative feedback mechanisms that bring the HPA to baseline levels [2].

In a wider sense, the HPA axis belongs to a more complex and integrated system built by many different tissues and organs of the body as well as a great number of nuclei in the nervous system. Whereas the HPA axis exhibits a clear axial conformation (the main features of the HPA axis regulation are represented in fig. 1), many of the molecules that constitute this axis, for instance CRH, AVP, ACTH, glucocorticoids, and all their receptors, are widely expressed throughout the brain and in a myriad of cells, tissues, and organs of the periphery $[2,5]$. All of these molecules maintain a close anatomical and functional cross-communication that establishes an intricate network where every molecular member has additive, synergistic, and complementary, as well as overlapping and compensatory, functions over other members of the network $[5,6]$. In this context, the elucidation of the molecular and physiological roles of the individual players in general, and of $\mathrm{CRH}$ in particular, in specific locations has been, and continues to be, one of the major challenges in neuroendocrinology.

\section{Extrahypothalamic CRH Coordinates the Integrated Response to Stress}

Besides the hypothalamus, $\mathrm{CRH}$ is widely distributed in extrahypothalamic circuits of the CNS [7] where it acts as a neuroregulator to develop and integrate a complex humoral and behavioral response to stress $[2,3,8,9]$. Many behavioral aspects of the integrated stress response such as locomotor activity, food intake, sexual behavior, sleep, arousal, anxiety, learning, and memory formation [8-10] are attributed to neuronal CRH projections including neocortical, limbic, and brainstem structures.

The CRH Network and the HPA Axis
Immunolabeling, radioimmunoassays, and in situ hybridization studies demonstrated that $\mathrm{CRH}$ and its receptors are extensively distributed in many diverse brain areas [11]. CRH receptor 1 (CRHR1) is expressed in high levels in the anterior pituitary, neocortical areas, basolateral and medial nuclei of the amygdala, hypothalamic nuclei, cerebellar Purkinje cells, lateral dorsal tegmentum, and pedunculopontine tegmental nucleus. CRH receptor 2 (CRHR2) has been detected in more discrete brain regions including the lateral septum, ventromedial hypothalamus, and cortical nucleus of the amygdala. Both receptors have been identified in the hippocampus [reviewed in 12]. The differential expression of CRH receptors (CRHRs) throughout the brain reflect the different actions that CRH exerts at the CNS level.

Alteration of the $\mathrm{CRH}$ system and chronically elevated levels of CRH are implicated in human stress-related affective disorders, mainly anxiety and depression $[2,4,13$, 14]. Central administration of $\mathrm{CRH}$ in rodents elicits phenotypic alterations reminiscent of symptoms of affective disorders [14]. Studies in animal models show that the behavioral and hormonal effects of CRH can be ascribed to CRHR1-mediated actions [15-17]. Clinical studies in humans also support that stress-induced CRH actions are mediated through binding to CRHR1 [14]. The functional role of stress-induced regulation of pituitary CRHR1 has been extensively characterized. Furthermore, studies on the function of this receptor in CNS areas have recently made progress with the help of conditional mouse models. Besides its role in behavioral responses, evidence suggesting that limbic CRHR1 is involved in feedback regulation of the HPA axis has been obtained [17].

\section{CRH Action: Understanding CRH Signaling at Cellular and Molecular Levels}

\section{CRH Receptors, Ligands, and Signaling Pathways}

$\mathrm{CRH}$ exerts its actions by activating two distinct Gprotein-coupled receptors (GPCRs), CRHR1 and CRHR2, which display different localization throughout the brain. Although both receptors, which are encoded by different genes, share about $70 \%$ amino acid identity, they have different ligand preferences due to lower similarity in their $\mathrm{N}$-terminal ligand-binding domains. $\mathrm{CRH}$ is a high-affinity ligand for CRHR1 and binds poorly to CRHR2, for which other CRH-related peptides such as urocortin II and III have higher affinity. Urocortin I binds with similar affinities to both CRHRs [18-20]. 
Fig. 1. HPA axis regulation and $\mathrm{CRH}$-induced ERK1/2 activation through CRHR1 in corticotrophs and in specific brain areas. The HPA axis and its regulation are depicted in the yellow-shaded area. In response to stress, hypothalamic neurons release the neuropeptides CRH and AVP, which act synergistically at the anterior pituitary to stimulate synthesis and release of ACTH. ACTH secreted from pituitary corticotrophs stimulates corticosteroid release from the adrenal cortex. The corticosteroids' negative feedback at the anterior pituitary and the hypothalamus is shown by dotted lines. The corticotrophs' schematic magnification showing $\mathrm{CRH}$-induced ERK1/2 activation (phosphorylation) through CRHR1, which leads to ACTH release, is depicted in the grayshaded area (details on CRH signaling in corticotrophs are shown in fig. 2). Effects on ERK1/2 activation in specific brain areas are shown in the upper part of the figure. Intracerebroventricular administrated $\mathrm{CRH}$ in mouse brain induces ERK1/2 phosphorylation (pERK1/2) in hippocampal CA1-CA3 areas and in the basolateral amygdalar complex (BLA). These structures are known to be involved in learning and memory, stress-related behaviors and sensory processing of multimodal stimuli. Conditional knockout mice carrying a forebrain-specific deletion of the CRHR1 (CrhrloxP/loxP Camk2acre) do not show CRH-induced ERK1/2 activation in these areas, compared to the control (CrhrloxP/loxP-control).

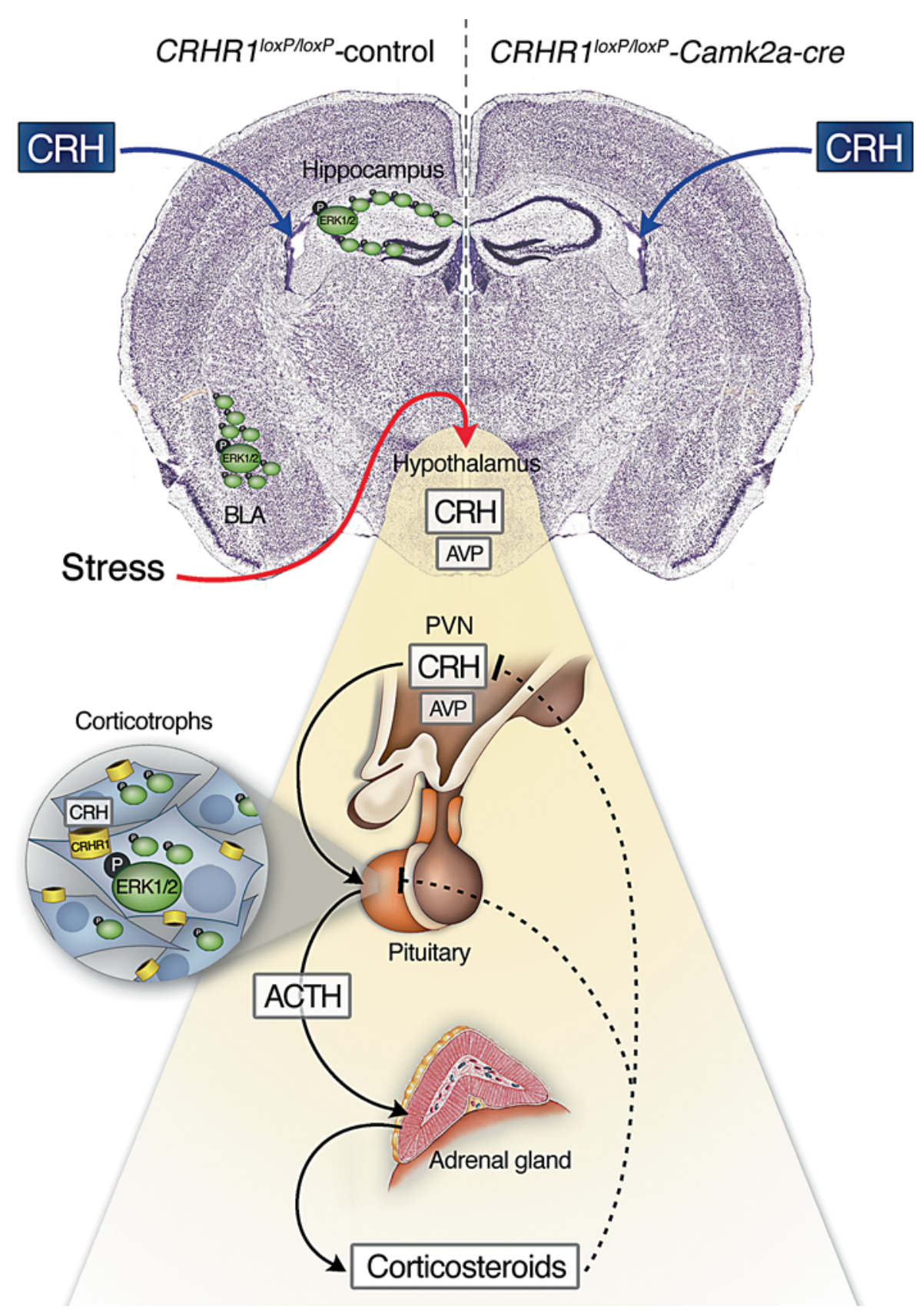

CRHRs belong to the class $\mathrm{B} /$ secretin-like receptor family [21], which binds polypeptide hormones. As a common feature of the family, they exhibit a number of diverse splicing variants that may contribute to tissuespecific differences in ligand-binding or receptor-signaling properties. Although several alternative splice forms of CRHR1 $(\alpha, \beta, c-n)$ have been identified in rodents and humans, CRHR $1 \alpha$ is the predominantly expressed and functional form [22]. CRHR2 has two isoforms in rodents
( $\alpha$ and $\beta)$ and three in humans $(\alpha, \beta$, and $\gamma)$ [23]. However, very little is known about the tissue-specific expression and the abundance of most splicing isoforms, their physiological relevance, and their possible role in determining biological responses.

In most systems, ligand-activated CRHRs signal by G $\alpha$ s coupling, resulting in adenylyl cyclase activation. Generation of second messenger cAMP, in turn, activates PKA, which phosphorylates downstream of cytosolic and 
nuclear targets, such as CREB, consequently inducing gene transcription. As previously mentioned, $\mathrm{CRH}$ and AVP stimulate the synthesis and release of ACTH in the pituitary. Both hormones exert their effects through GPCRs: CRHR1 and the V1b subtype vasopressin receptor (V1bR). A molecular cross-talk involving PKC activation (via V1bR) and cAMP-PKA (via CRHR1) is involved in CRH/AVP effects in mammalian corticotrophs. Recently, hetero-oligomerization between receptors for $\mathrm{CRH}$ and AVP from chicken pituitary [24] and mammalian corticotrophs [25] was reported. Interestingly, heterodimers coupled more efficiently to the Gs, which couple the CRHR to adenylyl cyclase [24]. Although these studies involve expression of fluorescently tagged receptors in vitro for FRET analysis, involvement of oligomerization as a mechanism to explain CRH potentiation by AVP is attractive.

Like most heptahelical GPCRs, CRHRs are linked to several intracellular signaling pathways besides the classical adenylyl cyclase activation, and are able to interact with multiple $G$ proteins to transmit signals to diverse intracellular effectors in an agonist and cell-specific manner $[5,26]$. Activation of MAPK cascades by CRHRs, as for other GPCRs, involves the participation of many different mediators in the signaling pathway [27]. Mechanisms involving heterotrimeric G-proteins, small G-proteins of the Ras family, and G-protein-independent activation via $\beta$-arrestin-mediated receptor desensitization have been found to be involved, depending on the system analyzed. One same receptor may utilize more than one mechanism in the same cellular context, defining distinct spatiotemporal characteristics of MAPK activation [28, 29].

\section{CRH Action in the Pituitary Corticotroph}

$\mathrm{CRH}$-stimulated corticotrophs from the anterior pituitary produce ACTH from a prohormone precursor proopiomelanocortin (POMC). Glucocorticoid release stimulated by ACTH gives negative feedback to both the hypothalamus and pituitary to inhibit synthesis and release of hypothalamic CRH and pituitary ACTH. Plasma levels of ACTH are tightly controlled to maintain the HPA axis equilibrium. Studies on $\mathrm{CRH}$ signaling have delineated the pathways involved in the activation of transcription factors that regulate POMC expression in the pituitary. In mouse pituitary cultures, CRH activation of CRHR1 was found to regulate POMC expression [16]. In AtT-20 mouse corticotrophs, a widely used cellular model to study $\mathrm{CRH}$ signaling and ACTH secretion, $\mathrm{CRH}$ activates via $\mathrm{PKA}$, the transcription factor $\mathrm{CREB}$, and the orphan receptor Nur77 $[19,29]$. The orphan nuclear receptors Nur77/NGFI-B, Nurrl, and NOR1 are particu-

The CRH Network and the HPA Axis larly important transcription factors involved in $\mathrm{CRH}-$ dependent POMC transcriptional regulation in corticotrophs [30, 31]. The molecular mechanisms involved in CRHR1-mediated signaling and transcriptional activation of POMC were investigated in AtT-20 cells. Upon endogenous CRHR1 activation by $\mathrm{CRH}$, a MAPK signal transduction pathway is activated, which is downstream of cAMP/PKA, to modulate POMC transcription. PKA triggers two main transduction pathways: one calciumindependent and another dependent on calcium entry through voltage-dependent calcium channels at the plasma membrane, involving calmodulin kinase II. ERK1/2 activation by $\mathrm{CRH}$ by both pathways in corticotrophs involves activation of the small G-protein Rap1, the B-Raf kinase, and ERK1/2. ERK1/2 regulate induction and activity of target transcription factors that induce POMC transcription, such as Nur77 and Nurr1 [32]. These results indicate that another layer of complexity is provided by $\mathrm{CRH}$ signaling through ERK1/2 as a consequence of increased levels of intracellular cAMP (fig. 2).

Negative feedback exerted by glucocorticoids is a critical feature of the HPA axis that is lost in ACTH-secreting adenomas, creating a hypercortisolemic state. GR leads to both inhibition of ACTH release and repression of POMC transcription, the latter involving transrepression mechanisms between GR and Nur factors [33]. Recent work demonstrated that the nuclear proteins Brg1 (the ATPase subunit of the chromatin remodeling complex Swi/Snif) and HDAC2 (histone deacetylase 2) scaffold a repression complex with GR and NGFI-B at the POMC gene. The high frequency of misexpression of these proteins in corticotroph adenomas supports their importance in the negative regulation of POMC [34]. In the same line, expression of BMP-4 (bone morphogenetic protein 4: a member of the TGF- $\beta$ family) is reduced in corticotrophinomas. BMP-4 has an inhibitory role on corticotroph tumorigenesis in vivo and is induced by retinoic acid, a negative regulator of Nur factors transcriptional activity $[35,36]$. It is noteworthy that BMP-4 inhibits CRH activation of MAPK pathways in AtT-20 corticotrophs, and it has been proposed that upregulation of BMP-4-signaling pathways by somatostatin analogs mediates the negative effect of these compounds in CRH-induced ACTH production [37].

\section{CRH Signaling Pathways Depending on Cellular Context}

As described in corticotrophs, ERK1/2 activation by $\mathrm{CRH}$ takes place via cAMP/PKA in CATH.a cells, an immortalized cell line that expresses endogenous CRHRs and resembles rat locus coeruleus neurons [38]. 
Fig. 2. CRH signaling in corticotrophs. Schematic representation focused on MAPK activation and Nur family transcription factors that specifically regulate expression of POMC, the ACTH precursor, in corticotrophs. Upon endogenous CRHR1 activation, corticotrophs trigger a MAPK signal transduction pathway, which is downstream of cAMP/PKA to modulate POMC transcription. PKA triggers two main transduction pathways: one is dependent on calcium entry through voltage-dependent L-type calcium channels at the plasma membrane, involving calmodulin kinase II, whereas the other pathway is calcium independent. ERK1/2 activated (pERK1/2) by CRH by both pathways involves the small G-protein Rap1 and the B-Raf kinase. In the canonical sequence of MAPK activation (B-RafMEK1/2-ERK1/2), the signal is passed via phosphorylation through the kinase cascade. pERK1/2 regulate induction and activity of orphan transcription factors Nur77 and Nurr1.

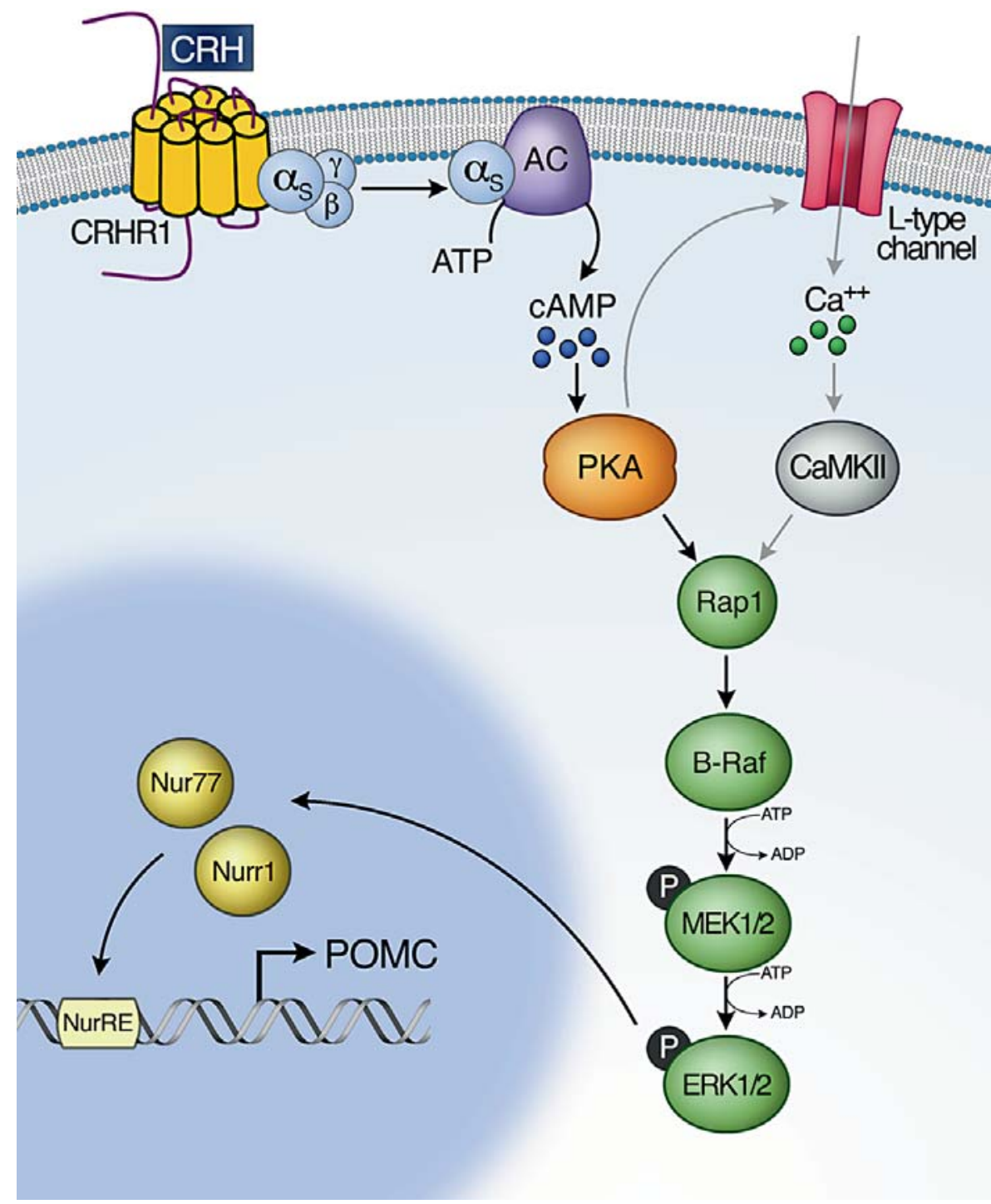

Insight into $\mathrm{CRH}$ signaling pathways was obtained from studies in peripheral cell lines overexpressing CRHRs. In HEK293 cells stably transfected with CRHR1, $\mathrm{CRH}$ is able to trigger cAMP through activation of Gos [39], but it is ineffective in activating ERK1/2 [40]. However, urocortin I activates ERK1/2 and p38 in the same cell system [41]. Urocortin I was found to couple CRHR1 to $\mathrm{Gq} /$ phospholipase C/IP3/PKC pathways, with PI3K having a critical role of in the regulation of ERK1/2, but was dispensable for p38 activation. Urocortin-triggered $\beta$-arrestin-mediated CRHR1 internalization was found involved in MAPK activation in this cell line [41].

The intracellular pathways by which CRHR1 activates the signal transduction cascades are only partially under- stood. Taken together, results obtained in recent years indicate that $\mathrm{CRH}$ activates, via the same receptor, different pathways in different cells and link the studies of $\mathrm{CRH} /$ CRHR1 signaling to the concept of signal transduction pathways that depend on intracellular context [29].

Studies on the attenuation of CRHR1 signaling through cAMP/PKA in HEK293 cells demonstrated the requirement of receptor phosphorylation by the GPCR kinases and binding to modulatory proteins like $\beta$-arrestins [42]. Parallel examination of CRH-triggered endocytosis in CRHR1-transfected primary cortical neurons and HEK293 cells showed requirement of $\beta$-arrestin- 2 , although receptors were internalized in distinct endocytic vesicles [43]. The kinetics of CRHR1 homologous 
desensitization/downregulation or resensitization differ considerably depending on cell type, which may reflect differences in the cellular expression of GPCR kinases and/or $\beta$-arrestin variants. Involvement of CRHR1 trafficking in crosstalk with other receptors was recently demonstrated. Enhanced serotonin signaling by $\mathrm{CRH}$ was shown to require $\mathrm{CRH}$-stimulated CRHR1 endocytosis and rapid recycling from endosomes, which resulted in increased cell surface expression of serotonin receptor, in both HEK293 cells and mouse cortical neurons [44]. $\beta$-Arrestin-binding physically prevents receptor G-protein interaction and promotes receptor endocytosis. $\beta$ Arrestins not only act as regulators of GPCR desensitization, but also as multifunctional adaptors that confer receptors the ability to initiate new, or sustain already initiated, ligand-triggered signaling mechanisms [28]. The involvement of a variety of molecular players in $\mathrm{CRH}$ signaling cascades may determine different kinetics of MAPK activation together with different location of the activated molecules and substrates.

\section{The B-Raf Kinase and MAPK Activation in CRH Signaling}

Both stimulatory and inhibitory effects of cAMP on ERK1/2 signaling have been observed depending on the cellular context. In cells in which cAMP stimulates ERK1/2 activity, B-Raf emerges as the decisive player of the canonical kinase cascade Raf-MEK1/2-ERK1/2. The B-Raf isoform of the Raf family of MAPK kinase kinases is highly expressed in neurons and in corticotrophs. Activated ERK1/2 phosphorylate numerous proteins that are responsible for transcriptional regulation. Distributed throughout the CNS and highly expressed in limbic brain areas, ERK1/2 are implicated in learning, memory, and neuroplasticity [45], acting also as molecular regulators of emotionally related behaviors [46].

In B-Raf-expressing cells, cAMP has at least two mechanisms to activate ERK through Rap1-dependent pathways: via PKA or by a PKA-independent direct activation of Rap1-GEFs or Epacs (exchange protein directly activated by cAMP). Both mechanisms can operate in the same cell [47]. As described before, CRHR1 activation in corticotrophs activates ERK1/2 in a PKA- and Rap1-dependent manner [32]. A recent work reported that a PKAindependent component, involving Epac2, also participates in ERK1/2 activation by CRH in corticotrophs [48].

Based on the fact that ERK1/2 activation through BRaf is caused by different stimuli including $\mathrm{CRH}[32,49]$ together with the crucial role of $\mathrm{B}$-Raf in ERK activation in the CNS [50], the identification of interacting partners of this intermediate kinase of the MAPK cascade will help clarify the intricacy of B-Raf-dependent signal transduction mechanisms and contribute to elucidating the signaling pathways of ERK1/2 activation [51]. Considering that biomolecular interactions play a crucial role in molecular processes, identifying interactors of this MAPK cascade is a promising approach to discover key components of $\mathrm{CRH}$ signaling in brain areas where $\mathrm{CRH}$ has a specific action. This may lead to the identification of pharmacological targets for pathologies associated with the CRH/CRHR1 system.

\section{CRH Action in the CNS: In vivo Studies}

\section{Understanding CRH Action in the CNS Using Mouse Models}

Hypothalamic $\mathrm{CRH}$ mediates neuroendocrine and autonomic responses through HPA activation, whereas central CRH modulates a wide range of adaptations, including anxiety-like behaviors. Studies on conventional knockout mice established the requirement of CRHR1 for endocrine responses to stress. CRHR1-null mice exhibit reduced anxiety-related behavior and an impaired basal and stress-induced HPA axis response, causing severe glucocorticoid deficiency [16]. To study the effects of central CRH hyperactivity in an animal model, $\mathrm{CRH}$ transgenic mouse lines were established expressing CRH either under the control of the broadly active metallothionein or the CNS-restricted Thy-1.2 promoter $[52,53]$. Unrestricted $\mathrm{CRH}$ overexpression resulted in elevated plasma ACTH and corticosterone levels accompanied by Cushing-like symptoms. Since glucocorticoids influence a variety of behavioral phenotypes, phenotypes derived from HPA alterations and CNS-derived CRH/CRHR1 behaviors cannot be distinguished in these models.

Recently, transgenic mouse lines were developed that allow the dissection of the CRH/CRHR1 system as the driver of the neuroendocrine stress response mediated by the HPA axis from its role as a modulator of complex behavioral responses in extrahypothalamic circuits. A conditional CRHR1 gene deletion, inactivated specifically in limbic structures but intact in the pituitary, allows the analysis of central CRH/CRHR1 function in the context of an intact basal and stress-induced HPA system. These mice are hypersensitive to stress and exhibit less anxietyrelated behavior [17]. Conditional CRH-overexpressing mouse lines that do not show significant neuroendocrine disturbances have been recently developed. Combining the knock-in of murine Crh cDNA into the ROSA26 lo- 
cus with the versatile Cre/LoxP system enables CRH overexpression in a spatiotemporally regulated fashion [54-56].

\section{CRH Signaling in the Brain: Studies in Animal Models}

Intracerebroventricular $\mathrm{CRH}$ administration in vivo induces a specific pattern of ERK1/2 activation in the mouse brain. In wild-type mice, ERK1/2 activation was detected in specific limbic areas as CA1-CA3 hippocampal pyramidal cell layers and the basolateral amygdalar complex. These structures are known to be related to environmental information processing and behavioral aspects of stress. Other regions such as hypothalamic nuclei and the central nucleus of the amygdala, also related to central CRH system but involved in the processing of the ascending visceral information and neuroendocrineautonomic response to stress, did not show CRH-mediated ERK1/2 activation [49]. CRHR1-dependency of ERK1/2 signaling in limbic areas was demonstrated in a mouse model carrying a forebrain-specific knockout of the CRHR1 [17]. These mice did not show CRH-mediated ERK1/2 activation in the hippocampus and basolateral amygdala [49]. The fact that acute CRH injection triggers such a specific ERK1/2 activation pattern even though ERK1/2 and CRHRs are widely expressed throughout the brain strongly suggests that a molecular and functional link between CRHR1 and downstream MAPK may be restricted to these brain structures [29]. Results on the analysis of ERK1/2 activation patterns in mouse brain after acute $\mathrm{CRH}$ administration are depicted in figure 1.

The effect of chronic CRH overexpression on ERK1/2 activation was analyzed under basal and stress conditions [57] using a transgenic mouse line in which $\mathrm{CRH}$ overexpression was restricted to limbic structures [54]. Phosphorylated ERK levels in the amygdala of CRHoverexpressing animals were decreased after $10 \mathrm{~min}$ of restraint stress, which increased plasma corticosterone concentrations in control and CRH-overexpressing animals. This treatment diminished CRHR1-binding capacity in the amygdala of the $\mathrm{CRH}$-overexpressing mice, suggesting that stress triggers a rapid internalization of the receptor and pointing to the reduced levels of phosphorylated ERK1/2 in this brain area [57]. In vivo evidence of stress-induced trafficking of CRHR1 has been reported in neurons $[58,59]$, and temporal aspects of receptor resensitization or turnover are expected to lead to specific effects in different brain areas. Such brain areaspecific effects await further investigation.

\section{Concluding Remarks}

$\mathrm{CRH}$ and its widely distributed receptors maintain a functional network that integrates the HPA axis with many brain nuclei and neuronal circuits. Understanding $\mathrm{CRH}$ function in specific locations is essential to find therapies for neuroendocrine and mood disorders.

Studies on the molecular mechanisms of CRHR1 signaling and internalization/downregulation in cellular models will be instrumental in finding targets of pharmacological intervention. The exploration of the characteristics of the MAPK activation by CRHR1 will contribute to the understanding of the plastic modulation of MAPK activity that controls the global cellular response to $\mathrm{CRH}$ in neuroendocrine tissues and different brain areas.

Chronically elevated $\mathrm{CRH}$ levels acting through CRHR1 in humans are associated with mood disorders, and blocking this receptor is a treatment option for those patients where CRH overactivity is a causal factor. Stress is a critical trigger for the initiation of these pathological processes. New genetically modified mice are suitable models for analyzing the relationship of chronic $\mathrm{CRH}$ overexpression, MAPK activation, and stress. Animals already obtained and new conditional mutants can be explored to dissect the contribution of these factors in the transition from physiological to pathological stress response. Animal models may also serve as an appropriate tool to discover new chemical entities muting excessive $\mathrm{CRH}$ production and release, and/or to develop and assay antagonists of CRHR1.

\section{Acknowledgments}

This work was supported by grants from the University of Buenos Aires, CONICET, and the Agencia Nacional de Promoción Científica y Tecnológica in Argentina, as well as the Max Plank Society and NeuroNova GmbH in Germany.

\footnotetext{
References

1 Vale W, Spiess J, Rivier C, Rivier J: Characterization of a 41-residue ovine hypothalamic peptide that stimulates secretion of corticotropin and beta-endorphin. Science 1981; 213:1394-1397.

2 de Kloet ER, Joels M, Holsboer F: Stress and the brain: from adaptation to disease. Nat Rev Neurosci 2005;6:463-475.

3 Smith SM, Vale WW: The role of the hypothalamic-pituitary-adrenal axis in neuroendocrine responses to stress. Dialogues Clin Neurosci 2006;8:383-395.
}

Bonfiglio/Inda/Refojo/Holsboer/Arzt/ Silberstein 
4 Holsboer F, Ising M: Stress hormone regulation: biological role and translation into therapy. Annu Rev Psychol 2010;61:81-109, C101-C111.

5 Hillhouse EW, Grammatopoulos DK: The molecular mechanisms underlying the regulation of the biological activity of corticotropin-releasing hormone receptors: implications for physiology and pathophysiology. Endocr Rev 2006;27:260-286.

-6 del Rey A, Besedovsky HO: The cytokineHPA axis circuit contributes to prevent or moderate autoimmune processes. Z Rheumatol 2000;59(Suppl 2):II/31-35.

-7 Swanson LW, Sawchenko PE, Rivier J, Vale WW: Organization of ovine corticotropinreleasing factor immunoreactive cells and fibers in the rat brain: an immunohistochemical study. Neuroendocrinology 1983; 36:165-186

$\checkmark 8$ Bale TL, Vale WW: CRF and CRF receptors: role in stress responsivity and other behaviors. Annu Rev Pharmacol Toxicol 2004;44: 525-557.

-9 Korosi A, Baram TZ: The central corticotropin releasing factor system during development and adulthood. Eur J Pharmacol 2008; 583:204-214.

-10 Steckler T, Holsboer F: Corticotropin-releasing hormone receptor subtypes and emotion. Biol Psychiatry 1999;46:1480-1508.

11 Gallagher JP, Orozco-Cabal LF, Liu J, Shinnick-Gallagher P: Synaptic physiology of central CRH system. Eur J Pharmacol 2008; 583:215-225.

12 Reul JM, Holsboer F: Corticotropin-releasing factor receptors 1 and 2 in anxiety and depression. Curr Opin Pharmacol 2002;2: 23-33.

13 Arborelius L, Owens MJ, Plotsky PM, Nemeroff CB: The role of corticotropin-releasing factor in depression and anxiety disorders. J Endocrinol 1999;160:1-12.

14 Holsboer F: The rationale for corticotropinreleasing hormone receptor (CRH-R) antagonists to treat depression and anxiety. J Psychiatr Res 1999;33:181-214.

-15 Smith GW, Aubry JM, Dellu F, Contarino A, Bilezikjian LM, Gold LH, Chen R, Marchuk Y, Hauser C, Bentley CA, Sawchenko PE, Koob GF, Vale W, Lee KF: Corticotropin releasing factor receptor 1-deficient mice display decreased anxiety, impaired stress response, and aberrant neuroendocrine development. Neuron 1998;20:1093-1102.

-16 Timpl P, Spanagel R, Sillaber I, Kresse A, Reul JM, Stalla GK, Blanquet V, Steckler T, Holsboer F, Wurst W: Impaired stress response and reduced anxiety in mice lacking a functional corticotropin-releasing hormone receptor 1. Nat Genet 1998;19:162166.
17 Muller MB, Zimmermann S, Sillaber I, Hagemeyer TP, Deussing JM, Timpl P, Kormann MS, Droste SK, Kuhn R, Reul JM, Holsboer F, Wurst W: Limbic corticotropinreleasing hormone receptor 1 mediates anxiety-related behavior and hormonal adaptation to stress. Nat Neurosci 2003;6:11001107.

18 Grigoriadis DE: The corticotropin-releasing factor receptor: a novel target for the treatment of depression and anxiety-related disorders. Expert Opin Ther Targets 2005;9: 651-684.

19 Hauger RL, Risbrough V, Brauns O, Dautzenberg FM: Corticotropin releasing factor $(\mathrm{CRF})$ receptor signaling in the central nervous system: new molecular targets. CNS Neurol Disord Drug Targets 2006;5:453479.

20 Holsboer F, Ising M: Central CRH system in depression and anxiety - evidence from clinical studies with CRH1 receptor antagonists. Eur J Pharmacol 2008;583:350-357.

21 Markovic D, Grammatopoulos DK: Focus on the splicing of secretin GPCRs transmembrane-domain 7. Trends Biochem Sci 2009;34:443-452.

22 Zmijewski MA, Slominski AT: Emerging role of alternative splicing of CRF1 receptor in CRF signaling. Acta Biochim Pol 2010;57: $1-13$.

23 Chen A, Perrin M, Brar B, Li C, Jamieson P, Digruccio M, Lewis K, Vale W: Mouse corticotropin-releasing factor receptor type $2 \mathrm{al}-$ pha gene: isolation, distribution, pharmacological characterization and regulation by stress and glucocorticoids. Mol Endocrinol 2005; 19:441-458.

24 Mikhailova MV, Mayeux PR, Jurkevich A, Kuenzel WJ, Madison F, Periasamy A, Chen $\mathrm{Y}$, Cornett LE: Heterooligomerization between vasotocin and corticotropin-releasing hormone $(\mathrm{CRH})$ receptors augments $\mathrm{CRH}$ stimulated 3',5'-cyclic adenosine monophosphate production. Mol Endocrinol 2007;21:2178-2188.

25 Young SF, Griffante C, Aguilera G: Dimerization between vasopressin V1b and corticotropin releasing hormone type 1 receptors. Cell Mol Neurobiol 2007;27:439-461.

26 Dautzenberg FM, Hauger RL: The CRF peptide family and their receptors: yet more partners discovered. Trends Pharmacol Sci 2002;23:71-77.

27 Brar BK, Chen A, Perrin MH, Vale W: Specificity and regulation of extracellularly regulated kinase1/2 phosphorylation through corticotropin-releasing factor (CRF) receptors 1 and 2beta by the CRF/urocortin family of peptides. Endocrinology 2004;145: 1718-1729.

28 Lefkowitz RJ, Shenoy SK: Transduction of receptor signals by beta-arrestins. Science 2005;308:512-517.

29 Arzt E, Holsboer F: CRF signaling: molecular specificity for drug targeting in the CNS. Trends Pharmacol Sci 2006;27:531-538.
30 Maira M, Martens C, Philips A, Drouin J: Heterodimerization between members of the Nur subfamily of orphan nuclear receptors as a novel mechanism for gene activation. Mol Cell Biol 1999;19:7549-7557.

- 31 Maira M, Martens C, Batsche E, Gauthier Y, Drouin J: Dimer-specific potentiation of NGFI-B (Nur77) transcriptional activity by the protein kinase A pathway and AF-1-dependent coactivator recruitment. Mol Cell Biol 2003;23:763-776.

32 Kovalovsky D, Refojo D, Liberman AC, Hochbaum D, Pereda MP, Coso OA, Stalla GK, Holsboer F, Arzt E: Activation and induction of NUR77/NURR1 in corticotrophs by CRH/cAMP: involvement of calcium, protein kinase A, and MAPK pathways. Mol Endocrinol 2002;16:1638-1651.

- 33 Martens C, Bilodeau S, Maira M, Gauthier Y, Drouin J: Protein-protein interactions and transcriptional antagonism between the subfamily of NGFI-B/Nur77 orphan nuclear receptors and glucocorticoid receptor. $\mathrm{Mol}$ Endocrinol 2005; 19:885-897.

- 34 Bilodeau S, Vallette-Kasic S, Gauthier Y, Figarella-Branger D, Brue T, Berthelet F, Lacroix A, Batista D, Stratakis C, Hanson J, Meij B, Drouin J: Role of Brg1 and HDAC2 in GR trans-repression of the pituitary POMC gene and misexpression in Cushing disease. Genes Dev 2006;20:2871-2886.

35 Giacomini D, Paez-Pereda M, Theodoropoulou M, Labeur M, Refojo D, Gerez J, Chervin A, Berner S, Losa M, Buchfelder M, Renner U, Stalla GK, Arzt E: Bone morphogenetic protein- 4 inhibits corticotroph tumor cells: involvement in the retinoic acid inhibitory action. Endocrinology 2006;147: 247-256.

36 Castillo V, Giacomini D, Paez-Pereda M, Stalla J, Labeur $M$, Theodoropoulou $M$, Holsboer F, Grossman AB, Stalla GK, Arzt E: Retinoic acid as a novel medical therapy for Cushing's disease in dogs. Endocrinology 2006;147:4438-4444.

- 37 Tsukamoto N, Otsuka F, Miyoshi T, Yamanaka $R$, Inagaki $K$, Yamashita $M$, Otani H, Takeda M, Suzuki J, Ogura T, Iwasaki Y, Makino H: Effects of bone morphogenetic protein (BMP) on adrenocorticotropin production by pituitary corticotrope cells: involvement of up-regulation of BMP receptor signaling by somatostatin analogs. Endocrinology 2010;151:1129-1141.

38 Cibelli G, Corsi P, Diana G, Vitiello F, Thiel G: Corticotropin-releasing factor triggers neurite outgrowth of a catecholaminergic immortalized neuron via cAMP and MAP kinase signalling pathways. Eur J Neurosci 2001;13:1339-1348.

- 39 Teli T, Markovic D, Hewitt ME, Levine MA Hillhouse EW, Grammatopoulos DK: Structural domains determining signalling characteristics of the CRH-receptor type 1 variant R1beta and response to PKC phosphorylation. Cell Signal 2008;20:40-49. 
40 Grammatopoulos DK, Randeva HS, Levine MA, Katsanou ES, Hillhouse EW: Urocortin, but not corticotropin-releasing hormone $(\mathrm{CRH})$, activates the mitogen-activated protein kinase signal transduction pathway in human pregnant myometrium: an effect mediated via R1alpha and R2beta CRH receptor subtypes and stimulation of Gq-proteins. Mol Endocrinol 2000;14:2076-2091.

41 Punn A, Levine MA, Grammatopoulos DK: Identification of signaling molecules mediating corticotropin-releasing hormoneRlalpha-mitogen-activated protein kinase (MAPK) interactions: the critical role of phosphatidylinositol 3-kinase in regulating ERK1/2 but not p38 MAPK activation. Mol Endocrinol 2006;20:3179-3195.

-42 Teli T, Markovic D, Levine MA, Hillhouse EW, Grammatopoulos DK: Regulation of corticotropin-releasing hormone receptor type 1alpha signaling: structural determinants for $\mathrm{G}$ protein-coupled receptor kinasemediated phosphorylation and agonistmediated desensitization. Mol Endocrinol 2005; 19:474-490.

$\checkmark 43$ Holmes KD, Babwah AV, Dale LB, Poulter MO, Ferguson SS: Differential regulation of corticotropin releasing factor lalpha receptor endocytosis and trafficking by beta-arrestins and Rab GTPases. J Neurochem 2006;96:934-949.

-44 Magalhaes AC, Holmes KD, Dale LB, Comps-Agrar L, Lee D, Yadav PN, Drysdale L, Poulter MO, Roth BL, Pin JP, Anisman H, Ferguson SS: CRF receptor 1 regulates anxiety behavior via sensitization of 5-HT2 receptor signaling. Nat Neurosci 2010;13:622629.
45 Thomas GM, Huganir RL: MAPK cascade signalling and synaptic plasticity. Nat Rev Neurosci 2004;5:173-183.

-46 Einat H, Yuan P, Gould TD, Li J, Du J, Zhang L, Manji HK, Chen G: The role of the extracellular signal-regulated kinase signaling pathway in mood modulation. J Neurosci 2003;23:7311-7316.

47 Stork PJ, Schmitt JM: Crosstalk between cAMP and MAP kinase signaling in the regulation of cell proliferation. Trends Cell Biol 2002;12:258-266.

48 Van Kolen K, Dautzenberg FM, Verstraeten K, Royaux I, De Hoogt R, Gutknecht E, Peeters PJ: Corticotropin releasing factorinduced ERK phosphorylation in AtT20 cells occurs via a cAMP-dependent mechanism requiring EPAC2. Neuropharmacology 2010;58:135-144.

49 Refojo D, Echenique C, Muller MB, Reul JM, Deussing JM, Wurst W, Sillaber I, Paez-Pereda M, Holsboer F, Arzt E: Corticotropin-releasing hormone activates ERK1/2 MAPK in specific brain areas. Proc Natl Acad Sci USA 2005;102:6183-6188.

50 Wiese S, Pei G, Karch C, Troppmair J, Holtmann B, Rapp UR, Sendtner M: Specific function of B-Raf in mediating survival of embryonic motoneurons and sensory neurons. Nat Neurosci 2001;4:137-142.

-51 Bonfiglio JJ, Maccarrone G, Rewerts C, Holsboer F, Arzt E, Turck CW, Silberstein S: Characterization of the B-Rafinteractome in mouse hippocampal neuronal cells. J Proteomics 2010;74:186-198.

52 Stenzel-Poore MP, Cameron VA, Vaughan J, Sawchenko PE, Vale W: Development of Cushing's syndrome in corticotropin-releasing factor transgenic mice. Endocrinology 1992;130:3378-3386.
53 GroeninkL, Dirks A, Verdouw PM, Schipholt $M$, Veening JG, van der Gugten J, Olivier B: HPA axis dysregulation in mice overexpressing corticotropin releasing hormone. Biol Psychiatry 2002;51:875-881.

54 Lu A, Steiner MA, Whittle N, Vogl AM, Walser SM, Ableitner M, Refojo D, Ekker M, Rubenstein JL, Stalla GK, Singewald N, Holsboer F, Wotjak CT, Wurst W, Deussing JM: Conditional mouse mutants highlight mechanisms of corticotropin-releasing hormone effects on stress-coping behavior. Mol Psychiatry 2008;13:1028-1042.

55 Kimura M, Muller-Preuss P, Lu A, Wiesner E, Flachskamm C, Wurst W, Holsboer F, Deussing JM: Conditional corticotropinreleasing hormone overexpression in the mouse forebrain enhances rapid eye movement sleep. Mol Psychiatry 2010;15:154-165.

56 Refojo D, Holsboer F: CRH signaling. Molecular specificity for drug targeting in the CNS. Ann NY Acad Sci 2009;1179:106-119.

57 Silberstein S, Vogl AM, Refojo D, Senin SA, Wurst W, Holsboer F, Deussing JM, Arzt E: Amygdaloid pERK1/2 in corticotropin-releasing hormone overexpressing mice under basal and acute stress conditions. Neuroscience 2009; 159:610-617.

58 Reyes BA, Valentino RJ, Van Bockstaele EJ: Stress-induced intracellular trafficking of corticotropin-releasing factor receptors in rat locus coeruleus neurons. Endocrinology 2008;149:122-130.

59 Waselus M, Nazzaro C, Valentino RJ, Van Bockstaele EJ: Stress-induced redistribution of corticotropin-releasing factor receptor subtypes in the dorsal raphe nucleus. Biol Psychiatry 2009;66:76-83. 